\title{
Sover du dårlig?
}

Kognitiv atferdsterapi og meditativ bevegelsestrening kan gi bedre søvnkvalitet.

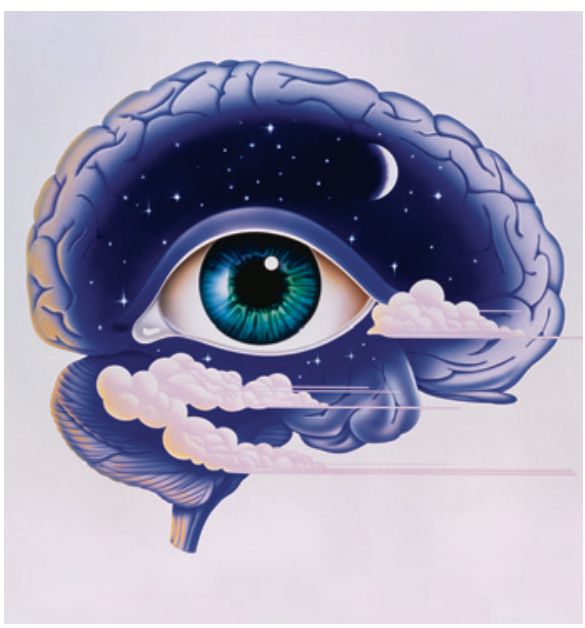

Illustrasjonsfoto: Science Photo Library
Søvnvansker er svært vanlig i befolkningen, særlig hos eldre, og kan behandles effektivt med flere ikke-medikamentelle tiltak.

I en studie ble 123 personer over 55 år med søvnvansker randomisert til kognitiv atferdsterapi, meditativ bevegelsestrening (tai chi) eller deltagelse på søvnseminar (1). Alle tiltakene ble gjennomført to timer ukentlig i fire måneder, og pasientene ble fulgt i 16 måneder.

Kognitiv atferdsterapi førte oftere til remisjon og ga bedre søvnkvalitet, mindre fatigue og færre depressive symptomer enn tai chi og søvnseminar. Tai chi førte til større bedring i søvnkvalitet, mindre fatigue og færre depressive symptomer enn søvnseminar, men ga ikke oftere remisjon.

- Denne studien har flere svakheter, påpeker Ulrik Fredrik Malt, professor i psykiatri ved Universitetet i Oslo. - Pasientene ble rekruttert via annonser og ikke fra allmennpraksis, og personer med psykiske lidelser, uregelmessig døgnrytme og røykere ble eks- kludert. Det samme gjaldt personer der søvnvansker ble antatt å være knyttet til somatisk sykdom. Bare to tredeler av dem som var inkluderbare, var villige til å delta i studien, som hadde en overvekt av kvinner, sier han.

- I klinisk praksis har over to tredeler av pasienter med søvnvansker en depressiv lidelse, sier Malt. - Samtidig kroppslig sykdom er også vanlig hos eldre pasienter med søvnvansker. Flere begrensninger gjør at resultatene i denne studien ikke er overførbare til pasienter i allmennpraksis uten videre, mener Malt.

\section{Ketil Slagstad}

Tidsskriftet

\section{Litteratur}

1. Irwin MR, Olmstead R, Carrillo $C$ et al. Cognitive behavioral therapy vs. Tai Chi for late life insomnia and inflammatory risk: a randomized controlled comparative efficacy trial. Sleep 2014; 37:1543-52.

\section{Beskytter amming mot diabetes?}

\section{Kvinner med svangerskapsdiabetes som ammer, reduserer risikoen for å utvikle type 2-diabetes sammenliknet med dem som ikke ammer, viser en ny studie.}

Amming gir en rekke helsefordeler for både mor og barn. Det er kjent at amming påvirker glukosemetabolismen i morens kropp, men hvorvidt det har en forebyggende effekt på utvikling av type 2-diabetes hos kvinner med svangerskapsdiabetes har vært usikkert.

Over 1000 kvinner med svangerskapsdiabetes ble fulgt $\mathrm{i}$ to år i en prospektiv kohortstudie (1). 11,8\% av dem utviklet type 2-diabetes. Det var en gradert, invers sammenheng mellom hvor lenge kvinnen ammet og risiko for diabetesutvikling: Kvinner som ammet i 2-5, 5-10 og over 10 måneder hadde en risiko for å få type 2-diabetes på henholdsvis $0,55,0,50$ og $0,43 \mathrm{i}$ forhold til dem som ammet i 0-2 måneder. I tillegg var risikoen lavere jo mindre moren brukte morsmelkerstatning.

- Funnene slutter seg til en økende rekke dokumenterte helsefordeler for kvinner som har ammet, sier Gro Nylander, tidligere overlege ved Nasjonal kompetansetjeneste for amming. - Studien har stor relevans for norske forhold, ettersom de fleste norske mødre ammer. På grunn av helsefordelene for mor og barn er det i dag ikke etisk mulig å gjøre randomiserte studier om amming, så nærmere sannheten enn dette kommer man neppe, sier hun.

\section{Kaveh Rashidi}

\section{Litteratur}

1. Gunderson EP, Hurston SR, Ning X et al. Lactation and progression to type 2 diabetes mellitus after gestational diabetes mellitus: a prospective cohort study. Ann Intern Med 2015: 163: 889-98.
Tidsskriftet

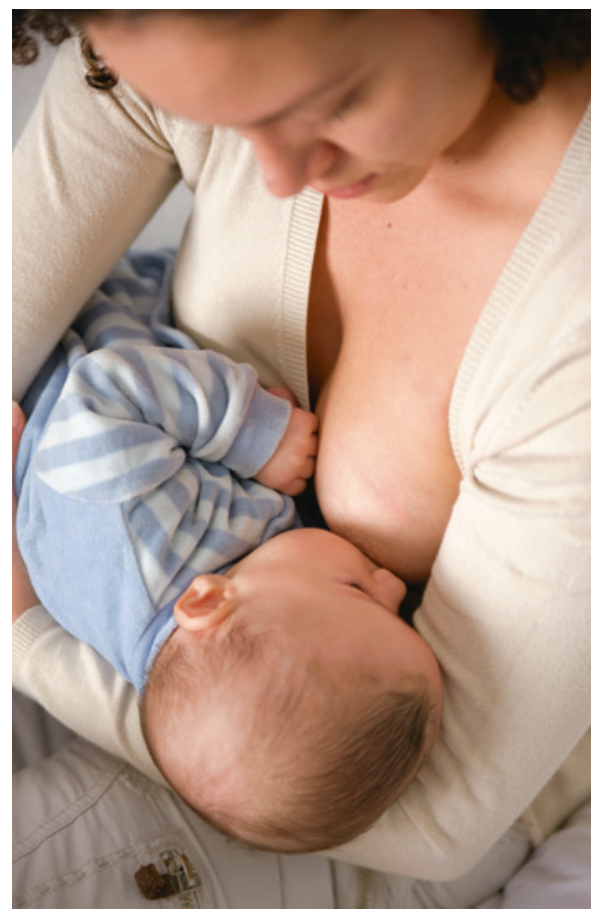

Illustrasjonsfoto: AGE/Scanpix 